\title{
Relative humidity-dependent viscosity of secondary organic material from toluene photo-oxidation and possible implications for organic particulate matter over megacities
}

Mijung Song ${ }^{1,2}$, Pengfei F. Liu ${ }^{3}$, Sarah J. Hanna ${ }^{1}$, Rahul A. Zaveri ${ }^{4}$, Katie Potter ${ }^{5}$, Yuan You ${ }^{1}$, Scot T. Martin ${ }^{3,6}$, and Allan K. Bertram ${ }^{1}$

${ }^{1}$ Department of Chemistry, University of British Columbia, Vancouver, BC, Canada

${ }^{2}$ Department of Earth and Environmental Sciences, Chonbuk National University, Jeollabuk-do, Republic of Korea

${ }^{3}$ John A. Paulson School of Engineering and Applied Sciences, Harvard University, Cambridge, MA, USA

${ }^{4}$ Atmospheric Sciences and Global Change Division, Pacific Northwest National Laboratory, Richland, WA, USA

${ }^{5}$ School of Chemistry, University of Bristol, Bristol, UK

${ }^{6}$ Department of Earth and Planetary Sciences, Harvard University, Cambridge, MA, USA

Correspondence to: Allan K. Bertram (bertram@chem.ubc.ca)

Received: 7 January 2016 - Published in Atmos. Chem. Phys. Discuss.: 29 January 2016

Revised: 30 May 2016 - Accepted: 31 May 2016 - Published: 19 July 2016

\begin{abstract}
To improve predictions of air quality, visibility, and climate change, knowledge of the viscosities and diffusion rates within organic particulate matter consisting of secondary organic material (SOM) is required. Most qualitative and quantitative measurements of viscosity and diffusion rates within organic particulate matter have focused on SOM particles generated from biogenic volatile organic compounds (VOCs) such as $\alpha$-pinene and isoprene. In this study, we quantify the relative humidity (RH)-dependent viscosities at $295 \pm 1 \mathrm{~K}$ of SOM produced by photo-oxidation of toluene, an anthropogenic VOC. The viscosities of toluene-derived SOM were $2 \times 10^{-1}$ to $\sim 6 \times 10^{6} \mathrm{Pas}$ from 30 to $90 \% \mathrm{RH}$, and greater than $\sim 2 \times 10^{8} \mathrm{Pas}$ (similar to or greater than the viscosity of tar pitch) for $\mathrm{RH} \leq 17 \%$. These viscosities correspond to Stokes-Einstein-equivalent diffusion coefficients for large organic molecules of $\sim 2 \times 10^{-15} \mathrm{~cm}^{2} \mathrm{~s}^{-1}$ for $30 \% \mathrm{RH}$, and lower than $\sim 3 \times 10^{-17} \mathrm{~cm}^{2} \mathrm{~s}^{-1}$ for $\mathrm{RH} \leq 17 \%$. Based on these estimated diffusion coefficients, the mixing time of large organic molecules within $200 \mathrm{~nm}$ toluene-derived SOM particles is $0.1-5 \mathrm{~h}$ for $30 \% \mathrm{RH}$, and higher than $\sim 100 \mathrm{~h}$ for $\mathrm{RH} \leq 17 \%$. As a starting point for understanding the mixing times of large organic molecules in organic particulate matter over cities, we applied the mixing times determined for toluene-derived SOM particles to the world's top 15 most
\end{abstract}

populous megacities. If the organic particulate matter in these megacities is similar to the toluene-derived SOM in this study, in Istanbul, Tokyo, Shanghai, and São Paulo, mixing times in organic particulate matter during certain periods of the year may be very short, and the particles may be wellmixed. On the other hand, the mixing times of large organic molecules in organic particulate matter in Beijing, Mexico City, Cairo, and Karachi may be long and the particles may not be well-mixed in the afternoon (15:00-17:00 LT) during certain times of the year.

\section{Introduction}

Volatile organic compounds (VOCs) are released into the atmosphere from both biogenic and anthropogenic sources. In the atmosphere, VOCs can form secondary organic material (SOM) through oxidation reactions with $\mathrm{OH}$ radicals, $\mathrm{NO}_{3}$ radicals, and $\mathrm{O}_{3}$. SOM accounts for $20-80 \%$ of the mass of organic atmospheric particulate matter at various locations (Zhang et al., 2007; Jimenez et al., 2009). SOM typically consists of thousands of different compounds, and only 10 $20 \%$ of the individual molecules that make up SOM particles have been identified (Decesari et al., 2006; Hallquist et al., 2009). The lack of information on the chemical composition 
of SOM has resulted in a poor understanding of their physical properties, including the viscosity and molecular diffusion rates within SOM particles.

Knowledge of the viscosity and molecular diffusion rates within SOM particles is needed to predict the properties of these particles and understand their role in the atmosphere. For example, the size distribution and mode diameter depend on the diffusion rates of organic molecules within the particles (Shiraiwa et al., 2013; Zaveri et al., 2014). Simulations show that total SOM mass concentrations can be overestimated or underestimated depending on what diffusion rates are used (Shiraiwa and Seinfeld, 2012). Chemical aging of atmospheric particles by heterogeneous reactions can depend on diffusion rates within SOM (Shiraiwa et al., 2011; Kuwata and Martin, 2012; Zhou et al., 2013; Steimer et al., 2014; Houle et al., 2015) and heterogeneous ice nucleation may be influenced by the viscosity of SOM particles (Murray et al., 2010; Wang et al., 2012; Ladino et al., 2014; Schill et al., 2014; Wilson et al., 2012). Moreover, long-range transport of polycyclic aromatic hydrocarbons can depend on diffusion rates in a particle (Zelenyuk et al., 2012; Zhou et al., 2013) and the efflorescence of crystalline salts can be hindered for highly viscous SOM (Murray, 2008; Murray and Bertram, 2008; Bodsworth et al., 2010; Song et al., 2013).

Most qualitative and quantitative measurements of viscosity and diffusion rates within organic particulate matter have focused on SOM generated from biogenic VOCs such as $\alpha$-pinene and isoprene (Virtanen et al., 2010; Cappa and Wilson, 2011; Perraud et al., 2012; Saukko et al., 2012; Abramson et al., 2013; Robinson et al., 2013; RenbaumWolff et al., 2013a; Bateman et al., 2015; Kidd et al., 2014; Pajunoja et al., 2014; Wang et al., 2015; Grayson et al., 2015; Song et al., 2015). Recently, the viscosity and diffusion rates within SOM particles generated from anthropogenic VOCs have also been investigated. Using mass spectrometry, Loza et al. (2013) and Robinson et al. (2013) investigated mixing of toluene-derived SOM particles and SOM particles from $\alpha$-pinene ozonolysis. Results from both studies were consistent with toluene-derived SOM being in a highly viscous state. From bounce experiments, Saukko et al. (2012) reported that SOM particles derived from naphthalene and n-heptadecane are highly viscous upon increasing oxidation. Also from bounce experiments, Bateman et al. (2015) showed SOM derived from photo-oxidation of toluene had a viscosity $>100 \mathrm{~Pa}$ s for relative humidity (RH) values $<80 \%$. Li et al. (2015) showed through bounce experiments that SOM derived from $m$-xylene and 1,3,5trimethylbenzene had a viscosity of $>100 \mathrm{~Pa}$ s at $\mathrm{RH}$ values less than $70 \%$. Li et al. (2015) also used results of reactive uptake studies to infer that for RH values of $35-45 \%$ the diffusion coefficient of carboxylic acids within SOM generated from several anthropogenic VOCs (toluene, m-xylene, and 1,3,5-trimethylbenzene) was $\sim 10^{-13.5 \pm 0.5} \mathrm{~cm}^{2} \mathrm{~s}^{-1}$. Although there has been recent progress in measuring the viscosity and diffusion rates within SOM generated from an- thropogenic VOCs, additional studies are needed to quantify the viscosities and diffusion rates over the full range of RH found in the atmosphere.

In the following, we measure the viscosities of toluenederived SOM over the range of $\mathrm{RH}$ values found in the atmosphere. As in previous studies, SOM from the photooxidation of toluene serves as a proxy for organic particulate matter from anthropogenic sources in megacities (e.g., Pandis et al., 1992; Robinson et al., 2013). After determining viscosities as a function of $\mathrm{RH}$, the Stokes-Einstein equation is used to convert the viscosities into equivalent diffusion rates of large organic molecules within toluene-derived SOM. The Stokes-Einstein equation should give reasonable values of diffusion rates when the viscosity is not near the viscosity of a glass $\left(\sim 10^{12} \mathrm{Pas}\right)$ and when the molecules are roughly the same size or larger than the molecules in the SOM matrix (Champion et al., 2000; Koop et al., 2011; Shiraiwa et al., 2011; Power et al., 2013). Finally, the results are used to estimate the viscosities and diffusion rates in organic particulate matter over megacities.

\section{Experimental}

The production and collection of SOM particles onto hydrophobic substrates (which are needed for the bead-mobility and poke-flow experiments) are discussed in Sect. 2.1. The viscosity of toluene-derived SOM was determined using the bead-mobility technique and the poke-flow technique together with simulations of fluid flow. These two techniques are discussed in Sects. 2.2 and 2.3.

\subsection{Production and collection of secondary organic material on hydrophobic substrates}

SOM aerosol particles having diameters less than $1 \mu \mathrm{m}$ were generated by toluene photo-oxidation in an oxidation flow reactor (OFR) (Kang et al., 2007; Lambe et al., 2011). The procedure for generating SOM from toluene photo-oxidation in the flow reactor has been given by Liu et al. (2015). Only the details relevant to the current experiments are given here.

For this study, the volume of the OFR was $13.3 \mathrm{~L}$ and the reactor was operated at a flow rate of $\sim 7 \mathrm{~L} \mathrm{~min}^{-1}$ with a residence time in the range of $\sim 110 \mathrm{~s}$. The temperature used in the OFR experiments was $293 \pm 2 \mathrm{~K}$ and the concentrations of toluene and ozone used in the flow reactor are listed in Table 1. Ozone was produced external to the flow reactor by irradiating pure air with the ultraviolet emission from an $\mathrm{Hg} \operatorname{lamp}(\lambda=185 \mathrm{~nm})$. The injected ozone concentration was $\sim 30 \mathrm{ppm}$. Hydroxyl radicals were produced inside the OFR by the following photochemical reactions:

$$
\begin{aligned}
& \mathrm{O}_{3}+h v(\lambda=254 \mathrm{~nm}) \rightarrow \mathrm{O}_{2}+\mathrm{O}\left({ }^{1} \mathrm{D}\right), \\
& \mathrm{O}\left({ }^{1} \mathrm{D}\right)+\mathrm{H}_{2} \mathrm{O} \rightarrow 2 \mathrm{OH} .
\end{aligned}
$$


Table 1. Experimental conditions for production and collection of toluene-derived SOM particles using the oxidation flow reactor. Particles were collected onto hydrophobic substrates using an electrostatic precipitator or a single-stage impactor.

\begin{tabular}{lrrrrrl}
\hline $\begin{array}{l}\text { SOM } \\
\text { sample } \\
\text { name }\end{array}$ & $\begin{array}{r}\text { Toluene } \\
\text { conc. } \\
(\mathrm{ppm})\end{array}$ & $\begin{array}{r}\text { Ozone } \\
\text { conc. } \\
(\mathrm{ppm})\end{array}$ & $\begin{array}{r}\text { SOM mass conc. } \\
\text { during production } \\
\left(\mu \mathrm{g} \mathrm{m}^{-3}\right)\end{array}$ & $\begin{array}{r}\text { OFR } \\
\text { flow rate } \\
\left(\mathrm{L} \mathrm{min}^{-1}\right)\end{array}$ & $\begin{array}{r}\text { Collection } \\
\text { time } \\
(\mathrm{h})\end{array}$ & $\begin{array}{l}\text { Collection } \\
\text { method }\end{array}$ \\
\hline \multicolumn{7}{c}{ For bead-mobility experiments } \\
\hline Toluene 1 & $1.0 \pm 0.1$ & $30 \pm 3$ & $600-1000$ & $7.0 \pm 0.5$ & 48 & Electrostatic precipitator \\
Toluene 2 & $1.0 \pm 0.1$ & $30 \pm 3$ & $600-1000$ & $7.0 \pm 0.5$ & 48 & Electrostatic precipitator \\
Toluene 3 & $0.1 \pm 0.01$ & $30 \pm 3$ & $60-100$ & $7.0 \pm 0.5$ & 12 & Impactor \\
Toluene 4 & $0.1 \pm 0.01$ & $30 \pm 3$ & $60-100$ & $7.0 \pm 0.5$ & 19 & Impactor \\
\hline \multicolumn{7}{c}{ For poke-flow experiments } \\
\hline Toluene 5 & $1.0 \pm 0.1$ & $30 \pm 3$ & $600-1000$ & $7.0 \pm 0.5$ & 96 & Electrostatic precipitator \\
Toluene 6 & $1.0 \pm 0.1$ & $30 \pm 3$ & $600-1000$ & $7.0 \pm 0.5$ & 96 & Electrostatic precipitator \\
Toluene 7 & $0.1 \pm 0.01$ & $30 \pm 3$ & $60-100$ & $7.0 \pm 0.5$ & 12.5 & Impactor \\
Toluene 8 & $0.1 \pm 0.01$ & $30 \pm 3$ & $60-100$ & $7.0 \pm 0.5$ & 16 & Impactor \\
\hline
\end{tabular}

The RH inside the reactor was held constant at $13 \pm 3 \%$. A recent study has shown that the viscosity of $\alpha$-pinene-derived SOM is dependent on the RH at which the SOM is generated (Kidd et al., 2014). Additional studies are needed to explore this potential RH effect on the viscosity of toluene-derived SOM.

Mass concentrations of SOM particles in the OFR were 60-100 and $600-1000 \mathrm{\mu g} \mathrm{m}^{-3}$ for the two different experimental conditions (see Table 1). For the mass concentration of $60-100 \mathrm{\mu g} \mathrm{m}^{-3}$, the oxygen-to-carbon $(\mathrm{O}: \mathrm{C})$ ratio was 1.08 , calculated from the AMS mass spectra following the approach of Chen et al. (2011). This value can be compared with the $\mathrm{O}: \mathrm{C}$ values ranging from 0.9 to 1.3 that were measured for toluene-derived SOM generated in a similar OFR (Lambe et al., 2015). At the outlet of the OFR, two different methods were used for the collection of SOM particles. In the first method, SOM particles were collected on hydrophobic slides using an electrostatic precipitator (TSI 3089, USA). After collection, the SOM particles on the hydrophobic slides, formed from coalescence during sampling, were smaller than $\sim 5 \mu \mathrm{m}$ in diameter. For the bead-mobility and poke-flow techniques, however, particle sizes 20-60 $\mu \mathrm{m}$ in diameter are needed. To generate these large sizes, the hydrophobic slides containing the SOM particles were placed inside an RH- and temperature-controlled flow cell (Pant et al., 2006; Bertram et al., 2011; Song et al., 2012) and the RH was increased to $>100 \%$. This procedure caused particle growth by water uptake and eventual coagulation among particles. This growth and coagulation process resulted in larger but fewer SOM particles on the hydrophobic slides. Details of this procedure are given by Renbaum-Wolff et al. (2015) and Song et al. (2015). This procedure was used for samples 1, 2, 5, and 6 shown in Table 1.

In the second method, SOM particles were collected on hydrophobic surfaces using a single-stage impactor (Prenni et al., 2009; Pöschl et al., 2010). During impaction, the collected submicron SOM particles coagulated, resulting in particles with sizes between 10 and $100 \mu \mathrm{m}$ in diameter. These supermicron particles were used directly in the bead-mobility and poke-flow experiments. This procedure was used to collect samples 3, 4, 7, and 8 shown in Table 1.

For all the bead-mobility experiments, a Teflon substrate was used. For all the poke-and-flow experiments, hydrophobic glass slides coated with trichloro $(1 H, 1 H, 2 H, 2 H-$ perfluorooctyl)silane (Sigma-Aldrich) were used. The coating procedure is described in Knopf (2003).

\subsection{Bead-mobility experiments}

The bead-mobility technique was previously described in Renbaum-Wolff et al. (2013a, b). Briefly, a water suspension of $\sim 1 \mu \mathrm{m}$ insoluble melamine beads (Sigma Aldrich Cat. no. 86296) was nebulized and incorporated into supermicron SOM particles deposited on a hydrophobic substrate (toluene samples 1-4, Table 1). The hydrophobic substrate with the SOM particles and beads was placed in a flow cell with variable $\mathrm{RH}$ and a temperature of $295 \pm 1 \mathrm{~K}$. A continuous flow of $\mathrm{N}_{2} / \mathrm{H}_{2} \mathrm{O}$ gas (flow rate $\approx 1200 \mathrm{sccm}$ ) was passed over the supermicron particles. The flow above the particles resulted in a shear stress on the particle surface and internal circulations within the particle, which could be visualized by observing the beads within the particles with a lighttransmitting microscope coupled to a CCD camera (Zeiss Axio Observer, magnification $40 \times$ ). Figure 1 shows images from a typical bead-mobility experiment for a toluenederived SOM particle at $80 \%$ RH. Typically, $1-7$ beads were monitored within a particle over 50-100 frames. The time between frames ranged from $0.2 \mathrm{~s}$ to 10 min depending on the velocity of the beads. From the location of the beads as a function of time, the speed of individual beads was determined. These individual speeds were then used to determine 


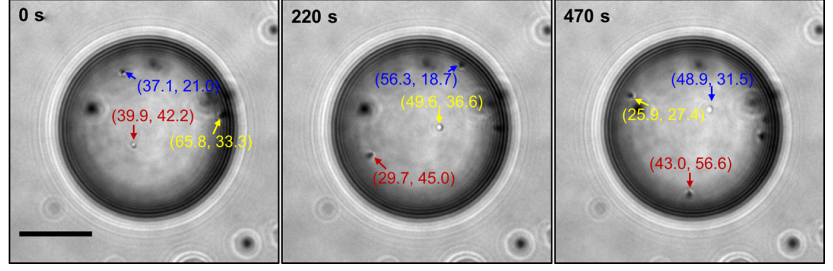

Figure 1. Optical images from typical bead-mobility experiments for a toluene-derived SOM particle (toluene sample 8 in Table 1) at $80 \% \mathrm{RH}$. Three different beads are labeled using colored arrows. The $x$ and $y$ coordinates of these beads are also indicated. Scale bar: $20 \mu \mathrm{m}$.

average bead speeds for a given sample and RH. The measured speeds of 3-10 beads were used to determine a mean bead speed. Bead speeds were not reported at $\mathrm{RH}<60 \%$ since at these $\mathrm{RH}$ values the movements of the beads were too slow to measure for typical observation times.

The average bead speed for a given sample and RH was converted to viscosity using a calibration line. The calibration line was developed by Song et al. (2015) from measurements of bead speeds in sucrose-water particles over a range of $\mathrm{RH}$ values. The RH within the flow cell was measured using a hygrometer with a chilled mirror sensor (General Eastern, Canada), which was calibrated by measuring the deliquescence RH for pure ammonium sulfate particles (80.0\% RH at $293 \mathrm{~K}$, Martin, 2000). The uncertainty of the hygrometer was $\pm 0.5 \% \mathrm{RH}$ after calibration.

\subsection{Poke-flow technique in conjunction with fluid simulations}

The poke-and-flow technique in conjunction with fluid simulations was used to measure the viscosities of SOM particles at $\mathrm{RH}$ values less than $50 \%$. This technique was not used at $\mathrm{RH}$ values $>50 \%$ since the flow rates of the SOM after poking were too fast to observe at these $\mathrm{RH}$ values. The qualitative method of poking an inorganic particle to determine its phase (i.e., solid or liquid) was introduced by Murray et al. (2012). Renbaum-Wolff et al. (2013a) and Grayson et al. (2015) expanded on this method by measuring the characteristic flow time of a material after poking and extracting viscosity information from simulations of fluid flow. Briefly, supermicron toluene-derived SOM particles deposited on a hydrophobic substrate (toluene 5-8, Table 1) were placed inside a flow cell with RH control. The particles were conditioned for $30 \mathrm{~min}$ at $>70 \% \mathrm{RH}, 60 \mathrm{~min}$ at $60-70 \% \mathrm{RH}, 2 \mathrm{~h}$ at $30-60 \% \mathrm{RH}$, and $3 \mathrm{~h}$ at $\leq 30 \% \mathrm{RH}$. These times should be sufficient for the particles to equilibrate with the surrounding water vapor based on recent measurements of diffusion coefficients of water within the water-soluble component of $\alpha$-pinene-derived SOM (Price et al., 2015). For example, the time to equilibrate with the surrounding of water vapor was calculated to be $25.3 \mathrm{~min}$ at $10 \% \mathrm{RH}$ based on diffusion co-

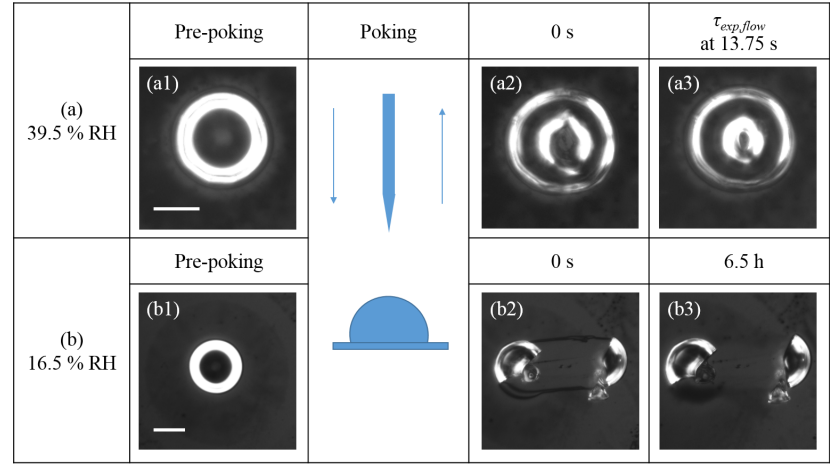

Figure 2. Optical images of pre-poking, poking, and post-poking from typical poke-flow experiments on toluene-derived SOM particles (toluene sample 6) at (a) $39.5 \% \mathrm{RH}$ and (b) $16.5 \% \mathrm{RH}$. Panels (a1, b1); pre-poking, panels (a2, b2) post-poking immediately after the needle has been removed (time set $=0 \mathrm{~s}$ ), panel (a3); the experimental flow time, $\tau_{\text {exp, flow }}$, where the diameter of hole has decreased to $50 \%$ of its initial size, and panel (b3) particles shatter and do not flow over a period of $6.5 \mathrm{~h}$. Scale bar: $20 \mu \mathrm{m}$.

efficients of water within the water-soluble component of $\alpha$ pinene-derived SOM (Price et al., 2015). These diffusion coefficients should be applicable to SOM derived from toluene studied here, since both SOMs have similar viscosities as a function of RH (compare Fig. 2 in Renbaum-Wolff et al., 2013a, with Fig. 5 below).

After equilibration, particles were poked using a sharp needle $(0.9 \mathrm{~mm} \times 40 \mathrm{~mm})$ (Becton-Dickson, USA) that was mounted to a micromanipulator (Narishige, model MO202U, Japan) and inserted through a small hole in the top of the flow cell. The geometrical changes before, during, and after poking a particle were recorded by a reflectance optical microscope (Zeiss Axio Observer, $40 \times$ objective) equipped with a CCD camera. At 30-50\% RH the action of poking the particles with the needle resulted in the material forming a half torus geometry (see Fig. 2a). From the images recorded after poking the particles, the experimental flow time, $\tau_{\text {exp, flow }}$, was determined. The experimental flow time was defined as the time taken for the equivalent-area diameter of the inside of the half torus geometry to reduce to $50 \%$ of the initial diameter. Here the equivalent-area diameter, $d$, is calculated as $d=(4 A / \pi)^{1 / 2}$ where $A$ represents the hole area (Reist, 1992). For RH $<20 \%$ the SOM particles shattered after poking, and no restorative flow was observed over

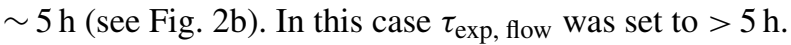

To determine viscosities from $\tau_{\text {exp flow }}$, simulations of fluid flow were carried out with the finite-element analysis software package, COMSOL Multiphysics (Renbaum-Wolff et al., 2013a; Grayson et al., 2015). The mesh size used in the simulations was $4.04-90.9 \mathrm{~nm}$. The physical parameters (i.e., slip length, surface tension, contact angle, and density) used in the simulation are listed in Table 2. 
Table 2. Physical parameters used to simulate material flow in the poke-flow experiments. $R$ and $r$ indicate the radius of a tube and the radius of an inner hole, respectively.

\begin{tabular}{lrrrr}
\hline & Slip length $(\mathrm{nm})$ & Surface tension $\left(\mathrm{mN} \mathrm{m}^{-1}\right)$ & Density $\left(\mathrm{g} \mathrm{cm}^{-3}\right)$ & Contact angle $^{\mathrm{e}}\left({ }^{\circ}\right)$ \\
\hline Values used to calculate lower limit & $5^{\mathrm{a}}$ & $28^{\mathrm{b}}$ & $1.4^{\mathrm{c}}$ & 80 (if $r<2 R), 100$ (if $r>2 R)$ \\
Values used to calculate upper limit & $10000^{\mathrm{a}}$ & $75^{\mathrm{d}}$ & $1.4^{\mathrm{c}}$ & 100 (if $r<2 R$ ), 80 (if $r>2 R)$ \\
\hline
\end{tabular}

${ }^{a}$ The range of slip length, which is the interactions between fluids and solid surfaces, is based on literature data (Schnell, 1956; Churaev et al., 1984; Watanabe et al., 1999; Baudry et al., 2001; Craig et al., 2001; Tretheway and Meinhart, 2002; Cheng and Giordano, 2002; Jin et al., 2004; Joseph and Tabeling, 2005; Neto et al., 2005; Choi and Kim, 2006; Joly et al., 2006; Zhu et al., 2012; Li et al., 2014). ${ }^{\text {b }}$ The lower limits of the surface tension of toluene-derived SOM were determined as $28 \mathrm{mN} \mathrm{m}^{-1}$, the surface tension of liquid toluene at $293 \mathrm{~K}$ (Adamson and Gast, 1997). ${ }^{\mathrm{c}} \mathrm{Ng}$ et al. (2007). ${ }^{\mathrm{d}}$ The upper limits of the surface tension of toluene-derived SOM were determined as $75 \mathrm{mN} \mathrm{m}{ }^{-1}$, the surface tension of pure water at $293 \mathrm{~K}$ (Engelhart et al., 2008). ${ }^{\mathrm{e}}$ Contact angle of the toluene-derived SOM on a substrate measured by 3-D fluorescence confocal microscope ranged 80-100 ${ }^{\circ}$ The relationship of viscosity and contact angle depends on the ratio of the radius of a tube, $R$, to the radius of an inner hole, $r$ (Grayson et al., 2015).

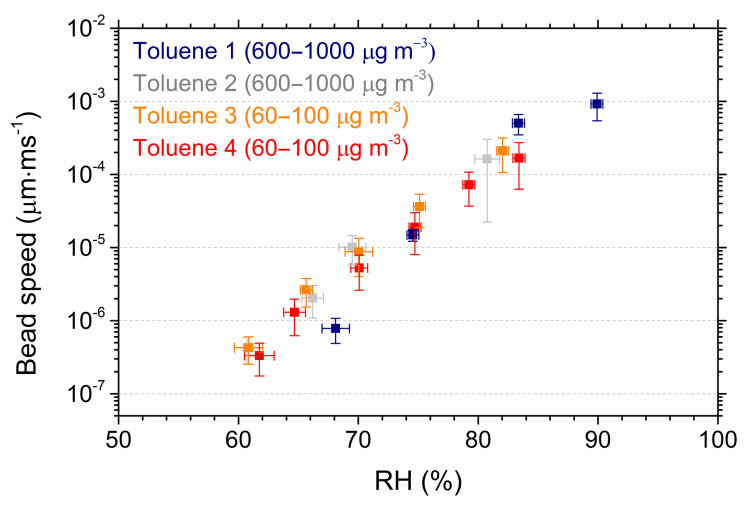

Figure 3. Measured average bead speeds as a function of RH for different SOM samples (toluene 1, 2, 3, and 4, see Table 1). The bead speeds of 3-10 beads were used to determine a mean bead speed. The $x$ error bars represent the uncertainty in the RH measurements and the range of $\mathrm{RH}$ values in a given experiment. The $y$ error bars represent the standard deviation of the measured bead speeds.

For each particle for which flow was observed, simulations were run using a half torus geometry, similar to the geometry observed in the experiments where flow was observed. The radius of the tube, $R$, in the half torus geometry and the radius of the hole, $r$, in the half torus geometry used in the simulations were based on the images recorded immediately after poking the particles with the needle. To determine viscosity for each particle, viscosity in the simulations was adjusted until $\tau_{\text {model, flow }}$ was within $1 \%$ of $\tau_{\text {exp, flow }}$.

In cases for which the particles cracked, simulations were run using a quarter-sphere model with one of the flat faces of the quarter sphere in contact with the substrate, similar to what was observed in the experiments (Renbaum-Wolff et al., 2013a). The diameter used for the quarter sphere was $20 \mu \mathrm{m}$. In this case we determined a lower limit to the viscosity by adjusting the viscosity in the simulation until the sharp edge of the quarter-sphere model moved by $0.5 \mu \mathrm{m}$ within $5 \mathrm{~h}$. A value of $0.5 \mu \mathrm{m}$ was used since this amount of movement could be observed in the optical microscope experiments.

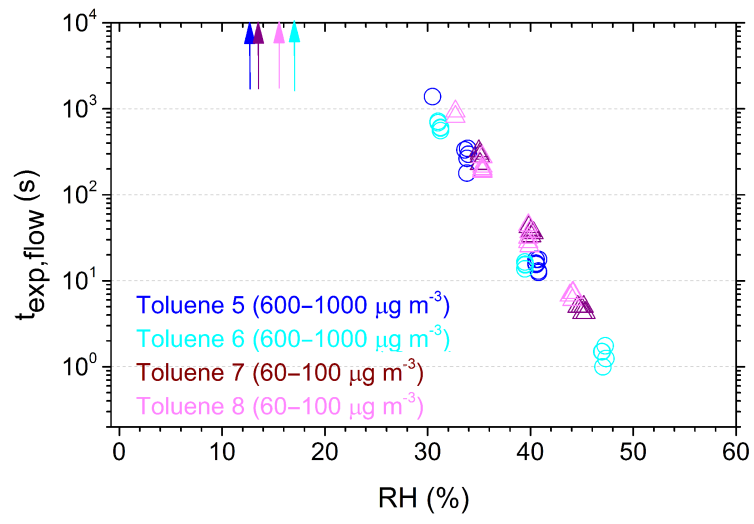

Figure 4. Results from poke-flow experiments. $\tau_{\text {exp, flow }}$, where the diameter of hole has decreased to $50 \%$ of its initial size, measured for the different samples (toluene 5, 6, 7, and 8, see Table 1). The arrows indicate particles shattered at the given $\mathrm{RH}$.

\section{Results}

Shown in Fig. 3 are the mean bead speeds of individual SOM samples (toluene 1, 2, 3, and 4) measured at different RH values between 60 and $90 \%$ RH (see Sect. 2.1). As the RH decreased from 89.9 to $60.7 \%$, the average bead speed decreased by a factor of 22 from $9.20 \times 10^{-4}$ to $4.24 \times 10^{-7} \mu \mathrm{m} \mathrm{ms}^{-1}$. Sample-to-sample variation was less than the uncertainty in the measurements and, within uncertainty, the results for $60-100 \mu \mathrm{g} \mathrm{m}^{-3}$ concentration agreed with the results for $600-1000 \mu \mathrm{g} \mathrm{m}^{-3}$ concentration.

Figure 4 shows the result of $\tau_{\text {exp, flow }}$ as a function of $\mathrm{RH}$ for the different samples (toluene $5,6,7$, and 8 ). The $\tau_{\text {exp } \text {, flow }}$ increased from $\sim 1$ to $\sim 2000 \mathrm{~s}$ as $\mathrm{RH}$ decreased from 50 to $30 \% \mathrm{RH}$.

Shown in Fig. 5 are the viscosities as a function of RH for toluene-derived SOM particles determined from the beadmobility experiments (Sect. 2.2) and the poke-flow experiments in conjunction with the fluid simulation (Sect. 2.3). For the bead-mobility experiments, the viscosities were determined from the mean of the bead speeds. The $y$ error bars indicate the $95 \%$ prediction intervals from the calibration line (Song et al., 2015). The $x$ error bars represent the uncer- 


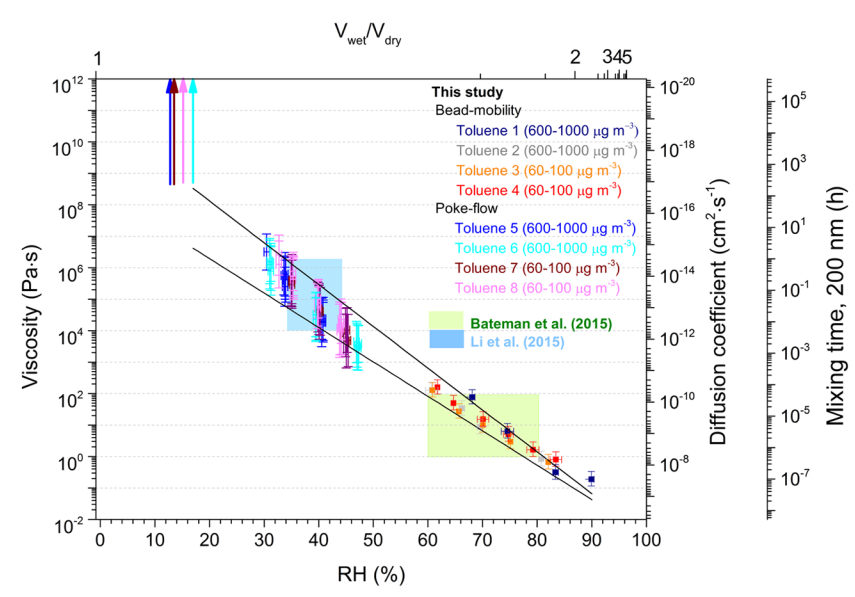

Figure 5. Viscosities of toluene-derived SOM particles as a function of RH. For $\mathrm{RH}>60 \%$ the viscosities were determined from the mean bead speeds (see Fig. 3) and a calibration line (Song et al., 2015). The $y$ error bars for $\mathrm{RH}>60 \%$ represent the $95 \%$ prediction intervals from the calibration line. For RH $<60 \%$ the viscosities were calculated from the $\tau_{\text {exp, flow where } y \text { error bars represent }}$ the calculated lower and upper limits of viscosity using the simulations. The $x$ error bars over the entire range of $\mathrm{RH}$ represent the range of RH values in a given experiments and the uncertainty in the $\mathrm{RH}$ measurements. The right $y$ axes present calculated diffusion coefficients of organic molecules in SOM using the Stokes-Einstein relation, and calculated mixing times within $200 \mathrm{~nm}$ particles due to bulk diffusion using Eq. (2). The black lines represent linear fits for the RH vs. $\log$ (lower viscosities) $\left(R^{2}=0.958\right)$ and $\log$ (upper viscosities) $\left(R^{2}=0.984\right)$ from the entire data set excluding the $\mathrm{RH}$ where particles cracked. Viscosity of toluene-derived SOM particles from Bateman et al. (2015) (green box) and Li et al. (2015) (blue box) is also included. The secondary $x$ axis shows $V_{\text {wet }} / V_{\text {dry }}$ of the SOM, where $V_{\text {dry }}$ is the volume of SOM at $0 \% \mathrm{RH}$ and $V_{\text {wet }}$ is the volume of the SOM after taking up water at a given RH.

tainty in the RH measurements. The viscosity of the SOM increases from $\sim 0.2$ to $\sim 129 \mathrm{~Pa}$ s as $\mathrm{RH}$ decreases from 89.9 to $60.7 \%$. As shown in Fig. 5, differences between the results for the 600-1000 and 60-100 $\mu \mathrm{g} \mathrm{m}^{-3}$ samples are less than the uncertainties in the measurements.

Also shown in Fig. 5 are the calculated viscosities of the toluene-derived SOM for $\mathrm{RH}<50 \%$ from the poke-flow experiments. The viscosity increases from approximately $7.8 \times 10^{3}$ to $6.3 \times 10^{6} \mathrm{Pas}$ as $\mathrm{RH}$ decreases from 47.3 to $30.5 \%$. The uncertainty in the viscosity of approximately 2 orders of magnitude arises from the uncertainties in the physical parameters used in the simulations (i.e. slip length, surface tension, density, and contact angle). Of these parameters, the slip length contributed the most to the uncertainty in the viscosity (Grayson et al., 2015). For RH $<20 \%$, restorative flow did not occur over $\sim 5 \mathrm{~h}$ resulting in a lower limit to the viscosity of $\sim 2 \times 10^{8} \mathrm{~Pa} \mathrm{~s}$, similar to or greater than the viscosity of tar pitch $\left(\sim 10^{8} \mathrm{~Pa}\right.$ s, Koop et al., 2011).

\section{Discussion}

Bateman et al. (2015) previously estimated the viscosity of toluene-derived SOM from particle rebound experiments. From their measurements, they estimated a viscosity of 100$1 \mathrm{~Pa}$ s for RHs between 60 and $80 \%$ with SOM mass concentrations of $30-50 \mu \mathrm{g} \mathrm{m}^{-3}$ (green box in Fig. 5), in good agreement with our measurements.

Li et al. (2015) previously estimated the diffusion coefficient of carboxylic acids within toluene-derived SOM from measurements of reactive uptake of $\mathrm{NH}_{3}$. They estimated a diffusion coefficient for carboxylic acids of $10^{-13.5 \pm 0.5} \mathrm{~cm}^{2} \mathrm{~s}^{-1}$ for RHs between 35 and $45 \%$ using SOM mass concentrations of $44-125 \mu \mathrm{g} \mathrm{m}^{-3}$. If a hydrodynamic radius of $0.1-1.5 \mathrm{~nm}$ is assumed for the carboxylic acids (Li et al., 2015), viscosity of $1 \times 10^{4}-2 \times 10^{6} \mathrm{~Pa} \mathrm{~s}$ is calculated using the Stokes-Einstein equation (blue box in Fig. 5), consistent with our measurements. The good agreement between the current results and the results from Bateman et al. (2015) and Li et al. (2015) suggests that the viscosity of the toluene-derived SOM is relatively insensitive to the particle mass concentrations at which the SOM is produced over the range of $30-1000 \mu \mathrm{g} \mathrm{m}^{-3}$.

The strong dependence of viscosity on RH shown in Fig. 5 can be understood by considering the hygroscopic nature of the SOM. To illustrate this point in Fig. 5, viscosity is also plotted vs. $V_{\text {wet }} / V_{\text {dry }}$ of the SOM (secondary $x$ axis), where $V_{\text {dry }}$ is the volume of SOM at $0 \% \mathrm{RH}$ and $V_{\text {wet }}$ is the volume of the SOM after taking up water at a given $\mathrm{RH}$. $V_{\text {wet }} / V_{\text {dry }}$ was calculated with the following equation (Petters and Kreidenweis, 2008; Pajunoja et al., 2015):

$V_{\text {wet }} / V_{\text {dry }}=\frac{\kappa}{\frac{100}{\mathrm{RH}}-1}+1$,

where $\kappa$ is the hygroscopic parameter. A hygroscopic parameter of 0.15 was assumed, consistent with previous measurements for toluene-derived SOM (Hildebrandt Ruiz et al., 2015). Equation (1) neglects the Kelvin effect, which is a reasonable assumption for the large particles used in our studies. Figure 5 illustrates that the water content (top $x$ axis) of the particles plays a key role in regulating the viscosity.

A liquid is defined as a material with a viscosity less than $10^{2} \mathrm{~Pa} \mathrm{~s}$; a semisolid is defined as a material with a viscosity between $10^{2}$ and $10^{12} \mathrm{~Pa} \mathrm{~s}$; and a solid is defined as a material with a viscosity greater than $10^{12} \mathrm{~Pa}$ (Koop et al., 2011; Shiraiwa et al., 2011). As shown in Fig. 5, the viscosities of the SOM produced from toluene photo-oxidation correspond to a liquid for $\mathrm{RH}>60 \%$, a semisolid for $60 \%<\mathrm{RH}<30 \%$, and a semisolid or a solid for $\mathrm{RH}<20 \%$. Our results suggest a semisolid-to-liquid phase transition at an RH between 60 and $70 \%$, in good agreement with Bateman et al. (2015) who suggested a semisolid-to-liquid phase transition of toluenederived SOM particles in the range of $60-80 \% \mathrm{RH}$.

From the viscosities determined at $295 \pm 1 \mathrm{~K}$ and the Stokes-Einstein relationship (assuming a hydrodynamic ra- 
dius of $0.4 \mathrm{~nm}$ for organic molecules within the toluenederived SOM, Renbaum-Wolff et al., 2013a), we calculated the diffusion coefficients of large organic molecules, $D_{\text {org }}$, within toluene-derived SOM (see secondary $y$ axis in Fig. 5). $D_{\text {org }}$ ranges from $\sim 3 \times 10^{-8}$ to $\sim 2 \times 10^{-15} \mathrm{~cm}^{2} \mathrm{~s}^{-1}$ for $\mathrm{RH}$ from 90 to $30 \%$. It is lower than $\sim 3 \times 10^{-17} \mathrm{~cm}^{2} \mathrm{~s}^{-1}$ for $\mathrm{RH} \leq 17 \%$. The Stokes-Einstein relation is not expected to predict with high accuracy the diffusion rates of small gas molecules such as $\mathrm{OH}, \mathrm{O}_{3}, \mathrm{NO}_{x}, \mathrm{NH}_{3}$, and $\mathrm{H}_{2} \mathrm{O}$ and may be inaccurate near the glass transition RH (Koop et al., 2011; Shiraiwa et al., 2011). However, the Stokes-Einstein relationship should give reasonable estimations of diffusion rates for large organic molecules for conditions not close to the glass transition temperature of the matrix (Champion et al., 2000; Koop et al., 2011; Shiraiwa et al., 2011; Power et al., 2013; Marshall et al., 2016).

Using the diffusion coefficients ( $D_{\text {org }}$ ), the mixing time by diffusion, $\tau_{\text {mixing }}$, of large organic molecules within a $200 \mathrm{~nm}$ SOM particle was calculated with the following equation, where $d$ is the particle diameter (Shiraiwa et al., 2011; Bones et al., 2012; Renbaum-Wolff et al., 2013a):

$\tau_{\text {mixing }}=\frac{d^{2}}{4 \pi^{2} D_{\text {org }}}$.

Here, we are using $200 \mathrm{~nm}$ to represent a typical accumulation mode atmospheric particle, Shiraiwa et al. (2011). The concentration of the diffusing molecules anywhere in the particles deviates by less than $e^{-1}$ from the homogeneously well-mixed case at times longer than $\tau_{\text {mixing }}$. The $\tau_{\text {mixing }}$ values calculated with this procedure are indicated in Fig. 5 (secondary $y$ axis). At an RH of $45 \%$ or higher, the mixing times are short, approaching a value less than or equal to $0.1 \mathrm{~h}$. At $30 \% \mathrm{RH}$, the mixing times are between 0.1 and $5 \mathrm{~h}$. At $\mathrm{RH} \leq 17 \%$, the mixing time is longer than $\sim 100 \mathrm{~h}$ (lower limit of the arrows in Fig. 5).

\section{Atmospheric implications}

In the following, we use the mixing times calculated in the previous section to estimate the mixing times of large organic molecules in organic particulate matter over megacities. Several caveats should be kept in mind when applying the mixing times discussed earlier to particles over megacities. First, organic particulate matter over megacities is most likely more complicated than toluene-derived SOM. Toluene and other aromatics can account for a large fraction of nonmethane hydrocarbon emission in urban environments (Singh et al., 1985; Na et al., 2005; Suthawaree et al., 2012), and toluene and aromatics are thought to be one of the main sources of SOM particles in urban environments (Odum et al., 1997; Schauer et al., 2002a, b; Vutukuru et al., 2006; Velasco et al., 2007, 2009; de Gouw et al., 2008; Gentner et al., 2012; Liu et al., 2012; Hayes et al., 2015). Nevertheless, large alkanes and unspeciated nonmethane organic gases also likely play a role in SOM formation in urban environments. Second, the toluene-derived SOM was generated using relatively large mass concentrations of particles (60$1000 \mu \mathrm{g} \mathrm{m}^{-3}$ ). The good agreement between our results and the results from Bateman et al. (2015) and Li et al. (2015), which were carried out with a mass concentration of 30$1000 \mathrm{\mu g} \mathrm{m}^{-3}$, suggests that for toluene-derived SOM the viscosity is not strongly dependent on the mass concentration of organics used to generated the SOM, but additional studies are needed to confirm this. Third, as mentioned above, the Stokes-Einstein equation was used to estimate diffusion coefficients and hence mixing times, and this equation can underestimate diffusion coefficients close to the glass transition temperature. Due to these caveats, the analysis below should be considered as a starting point for understanding the mixing times of large organic molecules in organic particulate matter particles over megacities. Additional studies are needed to explore the implications of the caveats discussed above.

For this analysis, we define megacity as a metropolitan area with a total population in excess of 10 million people. Based on the Population Division Data Query (2014) of the United Nations (http://esa.un.org/; United Nations, Department of Economic and Social Affairs, Population Division, 2014), we selected the top 15 most populous cities (Tokyo, Delhi, Shanghai, Mexico City, São Paulo, Mumbai, Osaka, Beijing, New York, Cairo, Dhaka, Karachi, Buenos Aires, Kolkata, and Istanbul) which meet this criterion.

In order to determine $\tau_{\text {mixing }}$ for organic particulate matter in megacities, information on the $\mathrm{RH}$ and temperature in the cities is needed. Figure 6 gives information on RH and temperature in the 15 most populous megacities obtained from NOAA's National Climatic Data Center (NCDC) (www.ncdc.noaa.gov). The figure shows boxplots of average afternoon (15:00-17:00 LT) RH and temperature from these cities for the years 2004-2014. The afternoon (15:0017:00 LT) was chosen for this analysis since this is the time of day when RH is typically the lowest. In the figure, the boxes represent the median, 25 th, and 75 th percentiles and the whiskers show the 10th and 90th percentiles. In addition to RH, viscosity can depend strongly on temperature (Champion et al., 1997; Koop et al., 2011). For example, the viscosity of solutions of sucrose and water may increase by 2-3 orders of magnitude for a $10 \mathrm{~K}$ decrease in temperature close to the glass transition temperature (Champion et al., 1997). However, the effect of temperature on the viscosity of toluene-derived SOM has not been quantified. As a result, we have limited the current analysis to months when the median afternoon temperature is within $5 \mathrm{~K}$ of the temperatures used in the viscosity measurements (i.e., 290-300 K). The fact that the median afternoon temperature is often below $290 \mathrm{~K}$, highlights the need for low-temperature viscosity measurements.

In Fig. 6, we indicate with green shading cases when the afternoon RH (at the 10th percentile level) does not go be- 

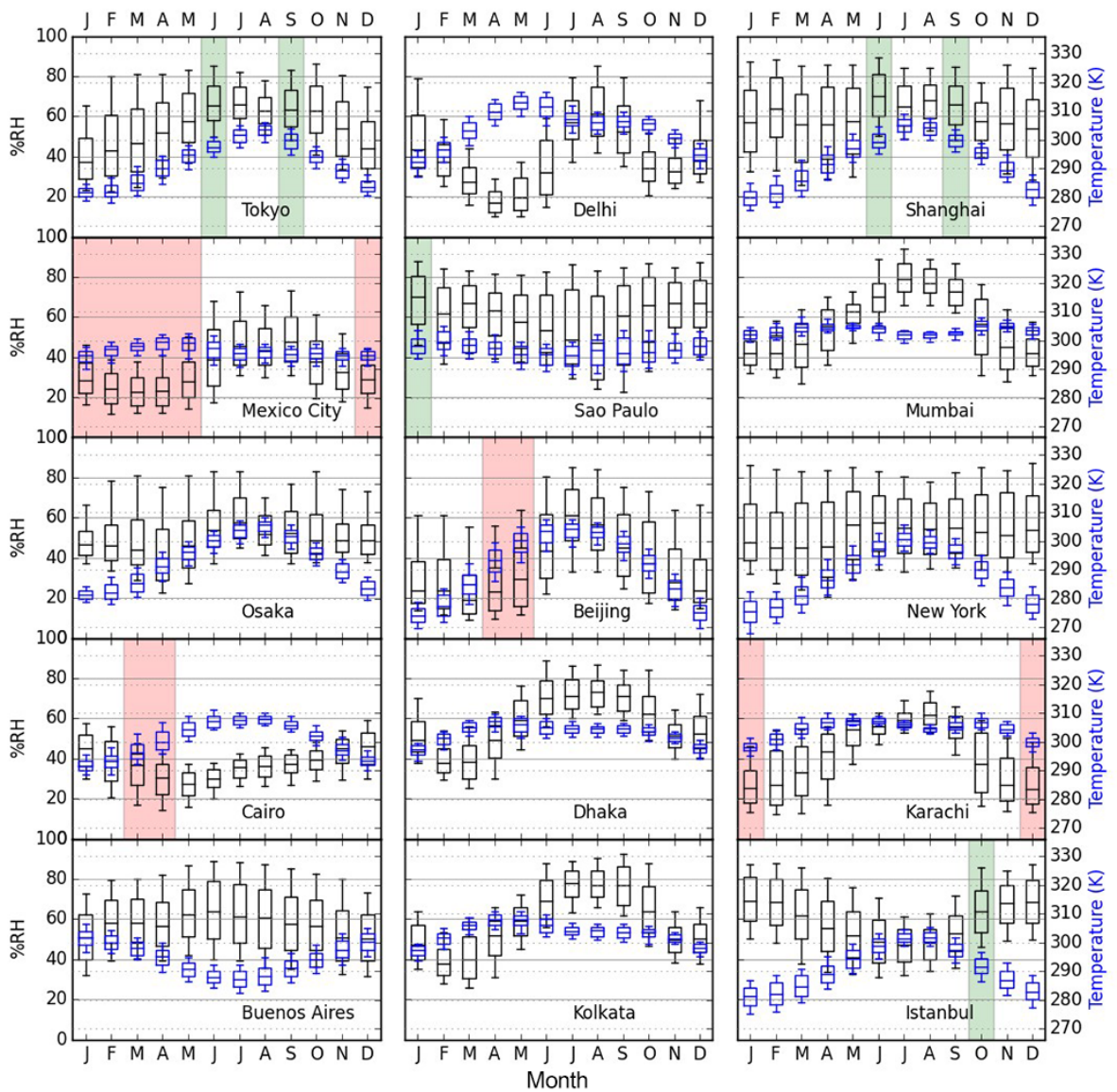

Figure 6. Monthly average RH and temperature for the megacities of Tokyo, Delhi, Shanghai, Mexico City, São Paulo, Mumbai, Osaka, Beijing, New York, Cairo, Dhaka, Karachi, Buenos Aires, Kolkata, and Istanbul. For the stations, afternoon averages RH values (15:0017:00 LT) were retrieved from NOAA's National Climate Data Center for the years from 2004 to 2014. Boxes show the median, 25th, and 75th percentiles of $3 \mathrm{~h}$ averages and the whiskers show the 10th and 90th percentiles. Green shading indicates that the afternoon RH (at the 10th percentile level) does not go below $45 \% \mathrm{RH}$ and the median afternoon temperature is $290-300 \mathrm{~K}$. Red shading indicates that the afternoon RH (at the 10th percentile level) is $17 \%$ or lower and the median afternoon temperature is $290-300 \mathrm{~K}$.

low $45 \% \mathrm{RH}$ and the median afternoon temperature is 290 $300 \mathrm{~K}$. The cases when the afternoon RH (at the 10th percentile level) does not go below $45 \% \mathrm{RH}$ are listed in Table 3 (second column). At $45 \%$ RH the mixing time within toluene-derived SOM is short (i.e., less than or equal to $0.1 \mathrm{~h}$ ). Figure 6 (green shading) and Table 3 suggest that, if the organic particulate matter over megacities is similar to the toluene-derived SOM in this study, in Tokyo, Shanghai, São Paulo, and Istanbul mixing times during certain periods of the year will be very short, and homogeneously well-mixed particles can be assumed.

In Fig. 6, we indicate with red shading cases where the afternoon RH (at the 10th percentile level) is $17 \%$ or lower and the median afternoon temperature is $290-300 \mathrm{~K}$. The cases when the afternoon RH (at the 10th percentile level) is $17 \%$ or lower are listed in Table 3 (third column). As mentioned above, at this $\mathrm{RH}$, the mixing time within toluene-derived SOM is long $(>100 \mathrm{~h})$, based on the viscosity measurements and Stokes-Einstein calculations. Figure 6 (red shading) and Table 3 (third column) suggest that if the organic particulate matter is similar to the toluene-derived SOM in this study, in Mexico City, Beijing, Cairo, and Karachi, the particles may not be well-mixed in the afternoon (15:00-17:00 LT) during certain times of the year.

Kleinman et al. (2009) studied the time evolution of aerosol size distributions and number concentrations of ambient particulate matter over the Mexico City plateau during the MILAGRO (Megacity Initiative: Local And Global Research Observations) field campaign conducted in March 2006. The particulate matter over Mexico City was primarily organic and as photochemical aging occurred, Kleinman and colleagues observed an increase in accumulation-mode volume due to an increase in the accumulation mode particles, not because of an increase in the average size of the accumulation mode. The condensing organic vapors from photo-oxidation of toluene and other 
Table 3. Months when the afternoon RH in the 15 most populous megacities either does not go below $45 \%$ (at the 10th percentile level) or is $17 \%$ or lower (at the 10th percentile level) and the median afternoon temperature is $290-300 \mathrm{~K}$. "None" indicates that these criteria are not met for any month.

\begin{tabular}{lll}
\hline Megacity & $\begin{array}{l}\text { Months when the after- } \\
\text { noon RH (at the 10th } \\
\text { percentile level) does } \\
\text { not go below 45\% }\end{array}$ & $\begin{array}{l}\text { Months when the after- } \\
\text { noon RH (at the 10th } \\
\text { percentile level) is 17\% } \\
\text { or lower }\end{array}$ \\
\hline Tokyo & Jun and Sep & none \\
Delhi & none & none \\
Shanghai & Jun and Sep & none \\
Mexico City & none & Jan-May, Dec \\
São Paulo & Jan & none \\
Mumbai & none & none \\
Osaka & none & none \\
Beijing & none & Apr and May \\
New York & none & none \\
Cairo & none & Mar-Apr \\
Dhaka & none & none \\
Karachi & none & Jan and Dec \\
Buenos Aires & none & none \\
Kolkata & none & none \\
Istanbul & Oct & none \\
\hline
\end{tabular}

anthropogenic VOCs over Mexico City are expected to be semivolatile (Shrivastava et al., 2013). However, Kleinman et al. (2009) showed that the observed evolution of aerosol size distribution was not consistent with a volume growth mechanism in which the semivolatile organic vapors are expected to readily diffuse within the accumulation mode substrate. This could indicate that the accumulation mode particles over Mexico City were highly viscous and did not reach equilibrium with large gas-phase organic molecules during the observation period. This observation is consistent with our experimental results that toluene-derived SOM is highly viscous at RH $<20 \%$ and Fig. 6, which shows that the median RH in Mexico City often falls below $20 \%$ in March. However, it should be noted that the particulate matter over Mexico City is likely more chemically complex than the SOM used in this study.

\section{Conclusions}

We investigated the $\mathrm{RH}$-dependent viscosities at room temperature of SOM particles produced from toluene photooxidation with the mass concentration of $60-1000 \mu \mathrm{g} \mathrm{m}^{-3}$. A bead-mobility technique showed the viscosities of the toluene-derived SOM increased from $\sim 0.2$ to $\sim 129 \mathrm{Pas}$ as RH decrease from 89.9 to $60.7 \%$. This indicates that the toluene-derived SOM particles are a liquid at $\mathrm{RH}>60 \%$. The RH range for liquid-to-semisolid is in good agreement with Bateman et al. (2015) who showed the liquidto-semisolid phase transition of these particles in the range

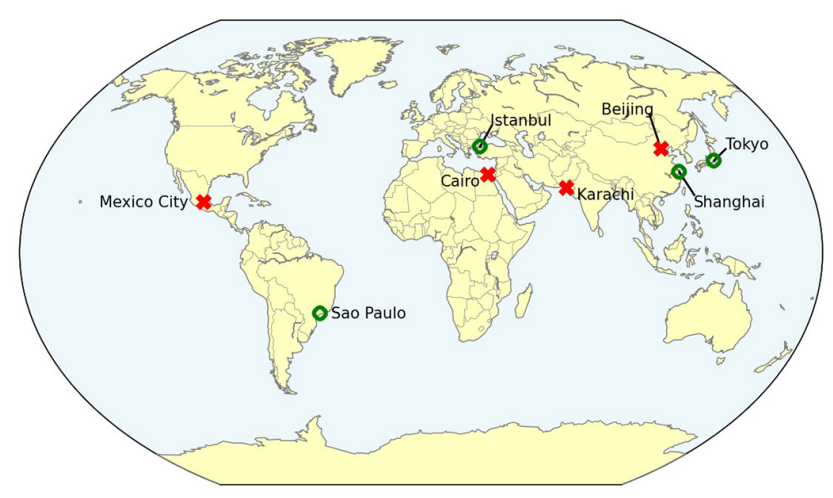

Figure 7. Summary of conclusions reached after applying the results of the viscosities, diffusion coefficients, and mixing time of the toluene-derived SOM to the top 15 most populous megacities. Green circles indicate megacities where the afternoon $\mathrm{RH}$ at the 10th percentile does not go below $45 \% \mathrm{RH}$ and the median afternoon temperature is $290-300 \mathrm{~K}$ for certain times of the year. In these cases, well-mixed particles can be assumed. Red crosses indicate megacities where the afternoon RH at the 10th percentile is $17 \%$ or lower for certain times of the year and the median afternoon temperature is $290-300 \mathrm{~K}$. In these cases, the particles may not be well mixed in the afternoon for certain times of the year.

of $60-80 \%$ RH. A poke-flow technique combined with fluid simulations showed the viscosities increased from approximately $7.8 \times 10^{3}$ to $6.3 \times 10^{6} \mathrm{Pas}$ as $\mathrm{RH}$ decreased from 47.3 to $30.5 \%$. For $\mathrm{RH} \leq 17 \%$, the viscosities of the SOM were greater than or equal to $\sim 2 \times 10^{8} \mathrm{Pas}$, similar to or greater than the viscosity of tar pitch. This suggests that the toluene-derived SOM particles are a semisolid at $20<\mathrm{RH} \leq 60 \%$, and a semisolid or a solid at $\mathrm{RH} \leq 17 \%$. Using the viscosity data and the Stokes-Einstein equation, the diffusion coefficients of large gas-phase organic molecules within the toluene-derived SOM particles were calculated to be $\sim 3 \times 10^{-8}$ to $\sim 2 \times 10^{-15} \mathrm{~cm}^{2} \mathrm{~s}^{-1}$ for RHs from 89.9 to $30.5 \%$, and is lower than $\sim 3 \times 10^{-17} \mathrm{~cm}^{2} \mathrm{~s}^{-1}$ for $\mathrm{RH} \leq 17 \%$. Mixing times by diffusion of large organic molecules within $200 \mathrm{~nm}$ toluene-derived SOM particles was calculated to be less than $0.1 \mathrm{~h}$ at $\mathrm{RH}>47.3 \%, 0.5-5 \mathrm{~h}$ at $30.5 \% \mathrm{RH}$, and greater than $\sim 100 \mathrm{~h}$ at $\mathrm{RH} \leq 17 \%$.

To apply the results of the viscosities, diffusion coefficients, and mixing time of the toluene-derived SOM, we selected the top 15 most populous megacities. Based on the RH in the cities, and if the organic particulate matter in megacities is similar to the toluene-derived SOM in this study, in cities such as Tokyo, Shanghai, São Paulo, and Istanbul, mixing times during certain periods of the year will be very short and homogeneously well-mixed particles can be assumed. On the other hand, for certain times of the year in Beijing, Mexico City, Cairo, and Karachi, mixing times of large organic molecules in organic particulate matter may be long $(\geq 100 \mathrm{~h})$, and the particles may not be well mixed in the af- 
ternoon (15:00-17:00 LT) during certain times of the year. These results are summarized in Fig. 7.

Acknowledgements. This work was supported by the Natural Sciences and Engineering Research Council of Canada. Support from the USA National Science Foundation, the Atmospheric Science Research (ASR) Program of the USA Department of Energy, the National Research Foundation of Korea (NRF) grant funded by the Korea Government (MSIP) (2016R1C1B1009243), and research funds for newly appointed professors of Chonbuk National University in 2015 is also acknowledged.

Edited by: B. Ervens

Reviewed by: two anonymous referees

\section{References}

Abramson, E., Imre, D., Beranek, J., Wilson, J., and Zelenyuk, A.: Experimental determination of chemical diffusion within secondary organic aerosol particles, Phys. Chem. Chem. Phys., 15, 2983-2991, doi:10.1039/C2cp44013j, 2013.

Adamson, A. W. and Gast, A. P.: Physical chemistry of surfaces, 6th Edn., Wiley, ISBN: 978-0-471-14873-9, 1997.

Bateman, A. P., Bertram, A. K., and Martin, S. T.: Hygroscopic influence on the semisolid-to-liquid transition of secondary organic materials, J. Phys. Chem. A., 119, 4386-4395, doi:10.1021/jp508521c, 2015.

Baudry, J., Charlaix, E., Tonck, A., and Mazuyer, D.: Experimental evidence for a large slip effect at a nonwetting fluid-solid interface, Langmuir, 17, 5232-5236, doi:10.1021/La0009994, 2001.

Bertram, A. K., Martin, S. T., Hanna, S. J., Smith, M. L., Bodsworth, A., Chen, Q., Kuwata, M., Liu, A., You, Y., and Zorn, S. R.: Predicting the relative humidities of liquid-liquid phase separation, efflorescence, and deliquescence of mixed particles of ammonium sulfate, organic material, and water using the organic-to-sulfate mass ratio of the particle and the oxygen-tocarbon elemental ratio of the organic component, Atmos. Chem. Phys., 11, 10995-11006, doi:10.5194/acp-11-10995-2011, 2011.

Bodsworth, A., Zobrist, B., and Bertram, A. K.: Inhibition of efflorescence in mixed organic-inorganic particles at temperatures less than $250 \mathrm{~K}$, Phys. Chem. Chem. Phys., 12, 15144-15144, 2010.

Bones, D. L., Reid, J. P., Lienhard, D. M., and Krieger, U. K.: Comparing the mechanism of water condensation and evaporation in glassy aerosol, P. Natl. Acad. Sci. USA, 109, 11613-11618, doi:10.1073/pnas.1200691109, 2012.

Cappa, C. D. and Wilson, K. R.: Evolution of organic aerosol mass spectra upon heating: implications for OA phase and partitioning behavior, Atmos. Chem. Phys., 11, 1895-1911, doi:10.5194/acp11-1895-2011, 2011.

Champion, D., Hervet, H., Blond, G., LeMeste, M., and Simatos, D.: Translational diffusion in sucrose solutions in the vicinity of their glass transition temperature, J. Phys. Chem. B, 101, 1067410679, doi:10.1021/jp971899i, 1997.

Champion, D., Le Meste, M., and Simatos, D.: Towards an improved understanding of glass transition and relaxations in foods: molecular mobility in the glass transition range, Trends Food Sci. Tech., 11, 41-55, doi:10.1016/S0924-2244(00)00047-9, 2000.
Chen, Q., Liu, Y. J., Donahue, N. M., Shilling, J. E., and Martin, S. T.: Particle-Phase Chemistry of Secondary Organic Material: Modeled Compared to Measured O : C and $\mathrm{H}: \mathrm{C}$ Elemental Ratios Provide Constraints, Environ. Sci. Technol., 45, 4763-4770, doi:10.1021/es104398s, 2011.

Cheng, J. T. and Giordano, N.: Fluid flow through nanometer-scale channels, Phys. Rev. E, 65, 031206, doi:10.1103/Physreve.65.031206, 2002.

Choi, C. H. and Kim, C. J.: Large slip of aqueous liquid flow over a nanoengineered superhydrophobic surface, Phys. Rev. Lett., 96, 066001, doi:10.1103/Physrevlett.96.066001, 2006.

Churaev, N. V., Sobolev, V. D., and Somov, A. N.: Slippage of liquids over lyophobic solid-surfaces, J. Colloid Interf. Sci., 97, 574-581, doi:10.1016/0021-9797(84)90330-8, 1984.

Craig, V. S. J., Neto, C., and Williams, D. R. M.: Shear-dependent boundary slip in an aqueous Newtonian liquid, Phys. Rev. Lett, 87, 054504, doi:10.1103/Physrevlett.87.054504, 2001.

Decesari, S., Fuzzi, S., Facchini, M. C., Mircea, M., Emblico, L., Cavalli, F., Maenhaut, W., Chi, X., Schkolnik, G., Falkovich, A., Rudich, Y., Claeys, M., Pashynska, V., Vas, G., Kourtchev, I., Vermeylen, R., Hoffer, A., Andreae, M. O., Tagliavini, E., Moretti, F., and Artaxo, P.: Characterization of the organic composition of aerosols from Rondônia, Brazil, during the LBASMOCC 2002 experiment and its representation through model compounds, Atmos. Chem. Phys., 6, 375-402, doi:10.5194/acp6-375-2006, 2006.

de Gouw, J. A., Brock, C. A., Atlas, E. L., Bates, T. S., Fehsenfeld, F. C., Goldan, P. D., Holloway, J. S., Kuster, W. C., Lerner, B. M., Matthew, B. M., Middlebrook, A. M., Onasch, T. B., Peltier, R. E., Quinn, P. K., Senff, C. J., Stohl, A., Sullivan, A. P., Trainer, M., Warneke, C., Weber, R. J., and Williams, E. J.: Sources of particulate matter in the northeastern United States in summer: 1. Direct emissions and secondary formation of organic matter in urban plumes, J. Geophys. Res.-Atmos., 113, D08301, doi:10.1029/2007jd009243, 2008.

Engelhart, G. J., Asa-Awuku, A., Nenes, A., and Pandis, S. N.: CCN activity and droplet growth kinetics of fresh and aged monoterpene secondary organic aerosol, Atmos. Chem. Phys., 8, $3937-$ 3949, doi:10.5194/acp-8-3937-2008, 2008.

Gentner, D. R., Isaacman, G., Worton, D. R., Chan, A. W. H., Dallmann, T. R., Davis, L., Liu, S., Day, D. A., Russell, L. M., Wilson, K. R., Weber, R., Guha, A., Harley, R. A., and Goldstein, A. H.: Elucidating secondary organic aerosol from diesel and gasoline vehicles through detailed characterization of organic carbon emissions, P. Natl. Acad. Sci. USA, 109, 18318-18323, doi:10.1073/pnas.1212272109, 2012.

Grayson, J. W., Song, M., Sellier, M., and Bertram, A. K.: Validation of the poke-flow technique combined with simulations of fluid flow for determining viscosities in samples with small volumes and high viscosities, Atmos. Meas. Tech., 8, 2463-2472, doi:10.5194/amt-8-2463-2015, 2015.

Hallquist, M., Wenger, J. C., Baltensperger, U., Rudich, Y., Simpson, D., Claeys, M., Dommen, J., Donahue, N. M., George, C., Goldstein, A. H., Hamilton, J. F., Herrmann, H., Hoffmann, T., Iinuma, Y., Jang, M., Jenkin, M. E., Jimenez, J. L., Kiendler-Scharr, A., Maenhaut, W., McFiggans, G., Mentel, Th. F., Monod, A., Prévôt, A. S. H., Seinfeld, J. H., Surratt, J. D., Szmigielski, R., and Wildt, J.: The formation, properties and impact of secondary organic aerosol: current and emerging issues, 
Atmos. Chem. Phys., 9, 5155-5236, doi:10.5194/acp-9-51552009, 2009.

Hayes, P. L., Carlton, A. G., Baker, K. R., Ahmadov, R., Washenfelder, R. A., Alvarez, S., Rappenglück, B., Gilman, J. B., Kuster, W. C., de Gouw, J. A., Zotter, P., Prévôt, A. S. H., Szidat, S., Kleindienst, T. E., Offenberg, J. H., Ma, P. K., and Jimenez, J. L.: Modeling the formation and aging of secondary organic aerosols in Los Angeles during CalNex 2010, Atmos. Chem. Phys., 15, 5773-5801, doi:10.5194/acp-15-5773-2015, 2015.

Hildebrandt Ruiz, L., Paciga, A. L., Cerully, K. M., Nenes, A., Donahue, N. M., and Pandis, S. N.: Formation and aging of secondary organic aerosol from toluene: changes in chemical composition, volatility, and hygroscopicity, Atmos. Chem. Phys., 15, 83018313, doi:10.5194/acp-15-8301-2015, 2015.

Houle, F. A., Hinsberg, W. D., and Wilson, K. R.: Oxidation of a model alkane aerosol by $\mathrm{OH}$ radical: the emergent nature of reactive uptake, Phys. Chem. Chem. Phys., 17, 4412-4423, 2015.

Jimenez, J. L., Canagaratna, M. R., Donahue, N. M., Prevot, A. S. H., Zhang, Q., Kroll, J. H., DeCarlo, P. F., Allan, J. D., Coe, H., Ng, N. L., Aiken, A. C., Docherty, K. S., Ulbrich, I. M., Grieshop, A. P., Robinson, A. L., Duplissy, J., Smith, J. D., Wilson, K. R., Lanz, V. A., Hueglin, C., Sun, Y. L., Tian, J., Laaksonen, A., Raatikainen, T., Rautiainen, J., Vaattovaara, P., Ehn, M., Kulmala, M., Tomlinson, J. M., Collins, D. R., Cubison, M. J., Dunlea, E. J., Huffman, J. A., Onasch, T. B., Alfarra, M. R., Williams, P. I., Bower, K., Kondo, Y., Schneider, J., Drewnick, F., Borrmann, S., Weimer, S., Demerjian, K., Salcedo, D., Cottrell, L., Griffin, R., Takami, A., Miyoshi, T., Hatakeyama, S., Shimono, A., Sun, J. Y., Zhang, Y. M., Dzepina, K., Kimmel, J. R., Sueper, D., Jayne, J. T., Herndon, S. C., Trimborn, A. M., Williams, L. R., Wood, E. C., Middlebrook, A. M., Kolb, C. E., Baltensperger, U., and Worsnop, D. R.: Evolution of organic aerosols in the atmosphere, Science, 326, 1525-1529, doi:10.1126/science.1180353, 2009.

Jin, S., Huang, P., Park, J., Yoo, J. Y., and Breuer, K. S.: Nearsurface velocimetry using evanescent wave illumination, Exp. Fluids, 37, 825-833, doi:10.1007/s00348-004-0870-7, 2004.

Joly, L., Ybert, C., and Bocquet, L.: Probing the nanohydrodynamics at liquid-solid interfaces using thermal motion, Phys. Rev. Lett., 96, 046101, doi:10.1103/Physrevlett.96.046101, 2006.

Joseph, P. and Tabeling, P.: Direct measurement of the apparent slip length, Phys. Rev. E, 71, 035303, doi:10.1103/Physreve.71.035303, 2005.

Kang, E., Root, M. J., Toohey, D. W., and Brune, W. H.: Introducing the concept of Potential Aerosol Mass (PAM), Atmos. Chem. Phys., 7, 5727-5744, doi:10.5194/acp-7-5727-2007, 2007.

Kidd, C., Perraud, V., Wingen, L. M., and Finlayson-Pitts, B. J.: Integrating phase and composition of secondary organic aerosol from the ozonolysis of alpha-pinene, P. Natl. Acad. Sci. USA, 111, 7552-7557, doi:10.1073/pnas.1322558111, 2014.

Kleinman, L. I., Springston, S. R., Wang, J., Daum, P. H., Lee, Y.-N., Nunnermacker, L. J., Senum, G. I., Weinstein-Lloyd, J., Alexander, M. L., Hubbe, J., Ortega, J., Zaveri, R. A., Canagaratna, M. R., and Jayne, J.: The time evolution of aerosol size distribution over the Mexico City plateau, Atmos. Chem. Phys., 9, 4261-4278, doi:10.5194/acp-9-4261-2009, 2009.

Knopf, D. A.: Thermodynamic properties and nucleation processes of upper tropospheric and lower stratospheric aerosol particles, Diss. ETH No. 15103, Zurich, Switzerland, 2003.
Koop, T., Bookhold, J., Shiraiwa, M., and Pöschl, U.: Glass transition and phase state of organic compounds: dependency on molecular properties and implications for secondary organic aerosols in the atmosphere, Phys. Chem. Chem. Phys., 13, 19238-19255, doi:10.1039/C1cp22617g, 2011.

Kuwata, M. and Martin, S. T.: Phase of atmospheric secondary organic material affects its reactivity, P. Natl. Acad. Sci. USA, 109, 17354-17359, doi:10.1073/pnas.1209071109, 2012.

Ladino, L. A., Zhou, S., Yakobi-Hancock, J. D., Aljawhary, D., and Abbatt, J. P. D.: Factors controlling the ice nucleating abilities of alpha-pinene SOA particles, J. Geophys. Res.-Atmos., 119, 9041-9051, 2014.

Lambe, A. T., Ahern, A. T., Williams, L. R., Slowik, J. G., Wong, J. P. S., Abbatt, J. P. D., Brune, W. H., Ng, N. L., Wright, J. P., Croasdale, D. R., Worsnop, D. R., Davidovits, P., and Onasch, T. B.: Characterization of aerosol photooxidation flow reactors: heterogeneous oxidation, secondary organic aerosol formation and cloud condensation nuclei activity measurements, Atmos. Meas. Tech., 4, 445-461, doi:10.5194/amt-4-445-2011, 2011.

Lambe, A. T., Chhabra, P. S., Onasch, T. B., Brune, W. H., Hunter, J. F., Kroll, J. H., Cummings, M. J., Brogan, J. F., Parmar, Y., Worsnop, D. R., Kolb, C. E., and Davidovits, P.: Effect of oxidant concentration, exposure time, and seed particles on secondary organic aerosol chemical composition and yield, Atmos. Chem. Phys., 15, 3063-3075, doi:10.5194/acp-15-3063-2015, 2015.

Li, L., Mo, J. W., and Li, Z. L.: Flow and slip transition in nanochannels, Phys. Rev. E, 90, 033003, doi:10.1103/Physreve.90.033003, 2014.

Li, Y. J., Liu, P. F. Gong, Z. Wang, Y., Bateman, A. P., Bergoend, C., Bertram, A. K., and Martin, S. T.: Chemical reactivity and liquid/non-liquid states of secondary organic material, Environ. Sci. Technol., 49, 13264-13274, doi:10.1021/acs.est.5b03392, 2015.

Liu, S., Ahlm, L., Day, D. A., Russell, L. M., Zhao, Y. L., Gentner, D. R., Weber, R. J., Goldstein, A. H., Jaoui, M., Offenberg, J. H., Kleindienst, T. E., Rubitschun, C., Surratt, J. D., Sheesley, R. J., and Scheller, S.: Secondary organic aerosol formation from fossil fuel sources contribute majority of summertime organic mass at Bakersfield, J. Geophys. Res.-Atmos., 117, D00v26, doi:10.1029/2012jd018170, 2012.

Liu, P. F., Abdelmalki, N., Hung, H.-M., Wang, Y., Brune, W. H., and Martin, S. T.: Ultraviolet and visible complex refractive indices of secondary organic material produced by photooxidation of the aromatic compounds toluene and $m$-xylene, Atmos. Chem. Phys., 15, 1435-1446, doi:10.5194/acp-15-1435-2015, 2015.

Loza, C. L., Coggon, M. M., Nguyen, T. B., Zuend, A., Flagan, R. C., and Seinfeld, J. H.: On the mixing and evaporation of secondary organic aerosol components, Environ. Sci. Technol., 47, 6173-6180, 2013.

Marshall, F. H., Miles, R. E. H., Song, Y.-C., Ohm, P. B., Power, R. M., Reid, J. P., and Dutcher, C. S.: Diffusion and reactivity in ultraviscous aerosol and the correlation with particle viscosity, Chem. Sci., 7, 1298-1308, doi:10.1039/C5SC03223G, 2016.

Martin, S. T.: Phase transitions of aqueous atmospheric particles, Chem. Rev., 100, 3403-3453, doi:10.1021/Cr990034t, 2000.

Murray, B. J.: Inhibition of ice crystallisation in highly viscous aqueous organic acid droplets, Atmos. Chem. Phys., 8, 54235433, doi:10.5194/acp-8-5423-2008, 2008. 
Murray, B. J. and Bertram, A. K.: Inhibition of solute crystallisation in aqueous $\mathrm{H}^{+}-\mathrm{NH}^{4+}-\mathrm{SO}_{4}^{2-}-\mathrm{H}_{2} \mathrm{O}$ droplets, Phys. Chem. Chem. Phys., 10, 3287-3301, 2008.

Murray, B. J., Wilson, T. W., Dobbie, S., Cui, Z. Q., Al-Jumur, S. M. R. K., Mohler, O., Schnaiter, M., Wagner, R., Benz, S., Niemand, M., Saathoff, H., Ebert, V., Wagner, S., and Karcher, B.: Heterogeneous nucleation of ice particles on glassy aerosols under cirrus conditions, Nat. Geosci., 3, 233-237, doi:10.1038/Ngeo817, 2010.

Murray, B. J., Haddrell, A. E., Peppe, S., Davies, J. F., Reid, J. P., O'Sullivan, D., Price, H. C., Kumar, R., Saunders, R. W., Plane, J. M. C., Umo, N. S., and Wilson, T. W.: Glass formation and unusual hygroscopic growth of iodic acid solution droplets with relevance for iodine mediated particle formation in the marine boundary layer, Atmos. Chem. Phys., 12, 8575-8587, doi:10.5194/acp-12-8575-2012, 2012.

Na, K., Moon, K. C., and Kim, Y. P.: Source contribution to aromatic VOC concentration and ozone formation potential in the atmosphere of Seoul, Atmos. Environ., 39, 5517-5524, doi:10.1016/j.atmosenv.2005.06.005, 2005.

Neto, C., Evans, D. R., Bonaccurso, E., Butt, H. J., and Craig, V. S. J.: Boundary slip in Newtonian liquids: a review of experimental studies, Rep. Prog. Phys., 68, 2859-2897, doi:10.1088/00344885/68/12/R05, 2005.

Ng, N. L., Kroll, J. H., Chan, A. W. H., Chhabra, P. S., Flagan, R. C., and Seinfeld, J. H.: Secondary organic aerosol formation from $m$-xylene, toluene, and benzene, Atmos. Chem. Phys., 7, 3909-3922, doi:10.5194/acp-7-3909-2007, 2007.

Odum, J. R., Jungkamp, T. P. W., Griffin, R. J., Flagan, R. C., and Seinfeld, J. H.: The atmospheric aerosol-forming potential of whole gasoline vapor, Science, 276, 96-99, doi:10.1126/science.276.5309.96, 1997.

Pajunoja, A., Malila, J., Hao, L. Q., Joutsensaari, J., Lehtinen, K. E. J., and Virtanen, A.: Estimating the Viscosity Range of SOA Particles Based on Their Coalescence Time, Aerosol Sci. Tech., 48, I-Iv, doi:10.1080/02786826.2013.870325, 2014.

Pajunoja, A., Lambe, A. T., Hakala, J., Rastak, N., Cummings, M. J., Brogan, J. F., Hao, L. Q., Paramonov, M., Hong, J., Prisle, N. L., Malila, J., Romakkaniemi, S., Lehtinen, K. E. J., Laaksonen, A., Kulmala, M., Massoli, P., Onasch, T. B., Donahue, N. M., Riipinen, I., Davidovits, P., Worsnop, D. R., Petaja, T., and Virtanen, A.: Adsorptive uptake of water by semisolid secondary organic aerosols, Geophys. Res. Lett., 42, 3063-3068, doi:10.1002/2015g1063142, 2015.

Pandis, S. N., Harley, R. A., Cass, G. R., and Seinfeld, J. H.: Secondary organic aerosol formation and transport, Atmos. Environ. A-Gen., 26, 2269-2282, 1992.

Pant, A., Parsons, M. T., and Bertram, A. K.: Crystallization of aqueous ammonium sulfate particles internally mixed with soot and kaolinite: Crystallization relative humidities and nucleation rates, J. Phys. Chem. A, 110, 8701-8709, doi:10.1021/Jp060985s, 2006.

Perraud, V., Bruns, E. A., Ezell, M. J., Johnson, S. N., Yu, Y., Alexander, M. L., Zelenyuk, A., Imre, D., Chang, W. L., Dabdub, D., Pankow, J. F., and Finlayson-Pitts, B. J.: Nonequilibrium atmospheric secondary organic aerosol formation and growth, P. Natl. Acad. Sci. USA, 109, 2836-2841, doi:10.1073/pnas.1119909109, 2012.
Petters, M. D. and Kreidenweis, S. M.: A single parameter representation of hygroscopic growth and cloud condensation nucleus activity - Part 2: Including solubility, Atmos. Chem. Phys., 8, 6273-6279, doi:10.5194/acp-8-6273-2008, 2008.

Pöschl, U., Martin, S. T., Sinha, B., Chen, Q., Gunthe, S. S., Huffman, J. A., Borrmann, S., Farmer, D. K., Garland, R. M., Helas, G., Jimenez, J. L., King, S. M., Manzi, A., Mikhailov, E., Pauliquevis, T., Petters, M. D., Prenni, A. J., Roldin, P., Rose, D., Schneider, J., Su, H., Zorn, S. R., Artaxo, P., and Andreae, M. O.: Rainforest aerosols as biogenic nuclei of clouds and precipitation in the Amazon, Science, 329, 1513-1516, doi:10.1126/science.1191056, 2010.

Power, R. M., Simpson, S. H., Reid, J. P., and Hudson, A. J.: The transition from liquid to solid-like behaviour in ultrahigh viscosity aerosol particles, Chem. Sci., 4, 2597-2604, doi:10.1039/C3sc50682g, 2013.

Prenni, A. J., Petters, M. D., Kreidenweis, S. M., Heald, C. L., Martin, S. T., Artaxo, P., Garland, R. M., Wollny, A. G., and Pöschl, U.: Relative roles of biogenic emissions and Saharan dust as ice nuclei in the Amazon basin, Nat. Geosci., 2, 401-404, doi:10.1038/Ngeo517, 2009.

Price, H. C., Mattsson, J., Zhang, Y., Bertram, A. K., Davies, J. F., Grayson, J. W., Martin, S. T., O’Sullivan, D., Reid, J. P., Rickards, A. M. J., and Murray, B. J.: Water diffusion in atmospherically relevant alpha-pinene secondary organic material, Chem. Sci., 6, 4876-4883, doi:10.1039/c5sc00685f, 2015.

Reist, P.: Aerosol Science and Technology, McGraw-Hill Professional, New York, NY, USA, 2nd Edn., 1992.

Renbaum-Wolff, L., Grayson, J. W., Bateman, A. P., Kuwata, M., Sellier, M., Murray, B. J., Shilling, J. E., Martin, S. T., and Bertram, A. K.: Viscosity of alpha-pinene secondary organic material and implications for particle growth and reactivity, P. Natl. Acad. Sci. USA, 110, 8014-8019, doi:10.1073/pnas.1219548110, 2013a.

Renbaum-Wolff, L., Grayson, J. W., and Bertram, A. K.: Technical Note: New methodology for measuring viscosities in small volumes characteristic of environmental chamber particle samples, Atmos. Chem. Phys., 13, 791-802, doi:10.5194/acp-13791-2013, 2013b.

Renbaum-Wolff, L., Song, M., Marcolli, C., Zhang, Y., Liu, P. F., Grayson, J. W., Geiger, F. M., Martin, S. T., and Bertram, A. K.: Observations and implications of liquid-liquid phase separation at high relative humidities in secondary organic material produced by a-pinene ozonolysis without inorganic salts, Atmos. Chem. Phys. Discuss., 15, 33379-33405, doi:10.5194/acpd-1533379-2015, 2015.

Robinson, E. S., Saleh, R., and Donahue, N. M.: Organic aerosol mixing observed by single-particle mass spectrometry, J. Phys. Chem. A, 117, 13935-13945, doi:10.1021/Jp405789t, 2013.

Saukko, E., Lambe, A. T., Massoli, P., Koop, T., Wright, J. P., Croasdale, D. R., Pedernera, D. A., Onasch, T. B., Laaksonen, A., Davidovits, P., Worsnop, D. R., and Virtanen, A.: Humiditydependent phase state of SOA particles from biogenic and anthropogenic precursors, Atmos. Chem. Phys., 12, 7517-7529, doi:10.5194/acp-12-7517-2012, 2012.

Schauer, J. J., Fraser, M. P., Cass, G. R., and Simoneit, B. R. T.: Source reconciliation of atmospheric gas-phase and particlephase pollutants during a severe photochemical smog episode, 
Environ. Sci. Technol., 36, 3806-3814, doi:10.1021/Es011458j, 2002a.

Schauer, J. J., Kleeman, M. J., Cass, G. R., and Simoneit, B. R. T.: Measurement of emissions from air pollution sources. 5. C-1-C32 organic compounds from gasoline-powered motor vehicles, Environ. Sci. Technol., 36, 1169-1180, doi:10.1021/Es0108077, 2002b.

Schill, G. P., De Haan, D. O., and Tolbert, M. A.: Heterogeneous ice nucleation on simulated secondary organic aerosol, Environ. Sci. Technol., 48, 1675-1682, 2014.

Schnell, E.: Slippage of Water over Nonwettable Surfaces, J. Appl. Phys., 27, 1149-1152, doi:10.1063/1.1722220, 1956.

Shiraiwa, M. and Seinfeld, J. H.: Equilibration timescale of atmospheric secondary organic aerosol partitioning, Geophys. Res. Lett., 39, L24801, doi:10.1029/2012gl054008, 2012.

Shiraiwa, M., Ammann, M., Koop, T., and Pöschl, U.: Gas uptake and chemical aging of semisolid organic aerosol particles, P. Natl. Acad. Sci. USA, 108, 11003-11008, doi:10.1073/pnas.1103045108, 2011.

Shiraiwa, M., Yee, L. D., Schilling, K. A., Loza, C. L., Craven, J. S., Zuend, A., Ziemann, P. J., and Seinfeld, J. H.: Size distribution dynamics reveal particle-phase chemistry in organic aerosol formation, P. Natl. Acad. Sci. USA, 110, 11746-11750, 2013.

Shrivastava, M., Zelenyuk, A., Imre, D., Easter, R., Beranek, J., Zaveri, R. A., and Fast, J.: Implications of low volatility SOA and gas-phase fragmentation reactions on SOA loadings and their spatial and temporal evolution in the atmosphere, J. Geophys. Res.-Atmos., 118, 3328-3342, 2013.

Singh, H. B., Salas, L. J., Cantrell, B. K., and Redmond, R. M.: Distribution of Aromatic Hydrocarbons in the Ambient Air, Atmos. Environ., 19, 1911-1919, doi:10.1016/0004-6981(85)90017-4, 1985.

Song, M., Marcolli, C., Krieger, U. K., Zuend, A., and Peter, T.: Liquid-liquid phase separation and morphology of internally mixed dicarboxylic acids/ammonium sulfate/water particles, Atmos. Chem. Phys., 12, 2691-2712, doi:10.5194/acp-12-26912012, 2012.

Song, M., Liu, P. F., Hanna, S. J., Li, Y. J., Martin, S. T., and Bertram, A. K.: Relative humidity-dependent viscosities of isoprene-derived secondary organic material and atmospheric implications for isoprene-dominant forests, Atmos. Chem. Phys., 15, 5145-5159, doi:10.5194/acp-15-5145-2015, 2015.

Song, M. J., Marcolli, C., Krieger, U. K., Lienhard, D. M., and Peter, T.: Morphologies of mixed organic/inorganic/aqueous aerosol droplets, Faraday Discuss., 165, 289-316, doi:10.1039/C3fd00049d, 2013.

Steimer, S. S., Lampimäki, M., Coz, E., Grzinic, G., and Ammann, M.: The influence of physical state on shikimic acid ozonolysis: a case for in situ microspectroscopy, Atmos. Chem. Phys., 14, 10761-10772, doi:10.5194/acp-14-10761-2014, 2014.

Suthawaree, J., Tajima, Y., Khunchornyakong, A., Kato, S., Sharp, A., and Kajii, Y.: Identification of volatile organic compounds in suburban Bangkok, Thailand and their potential for ozone formation, Atmos. Res., 104, 245-254, doi:10.1016/j.atmosres.2011.10.019, 2012.

Tretheway, D. C. and Meinhart, C. D.: Apparent fluid slip at hydrophobic microchannel walls, Phys. Fluids, 14, L9-L12, doi:10.1063/1.1432696, 2002.
United Nations, Department of Economic and Social Affairs, Population Division: World Urbanization Prospects: The 2014 Revision, custom data acquired via website, available at: https: //esa.un.org/unpd/wup/DataQuery/ (last access: 21 June 2016), 2014.

Velasco, E., Lamb, B., Westberg, H., Allwine, E., Sosa, G., ArriagaColina, J. L., Jobson, B. T., Alexander, M. L., Prazeller, P., Knighton, W. B., Rogers, T. M., Grutter, M., Herndon, S. C., Kolb, C. E., Zavala, M., de Foy, B., Volkamer, R., Molina, L. T., and Molina, M. J.: Distribution, magnitudes, reactivities, ratios and diurnal patterns of volatile organic compounds in the Valley of Mexico during the MCMA 2002 \& 2003 field campaigns, Atmos. Chem. Phys., 7, 329-353, doi:10.5194/acp-7-329-2007, 2007.

Velasco, E., Pressley, S., Grivicke, R., Allwine, E., Coons, T., Foster, W., Jobson, B. T., Westberg, H., Ramos, R., Hernandez, F., Molina, L. T., and Lamb, B.: Eddy covariance flux measurements of pollutant gases in urban Mexico City, Atmos. Chem. Phys., 9, 7325-7342, 2009.

Virtanen, A., Joutsensaari, J., Koop, T., Kannosto, J., Yli-Pirila, P., Leskinen, J., Makela, J. M., Holopainen, J. K., Pöschl, U., Kulmala, M., Worsnop, D. R., and Laaksonen, A.: An amorphous solid state of biogenic secondary organic aerosol particles, Nature, 467, 824-827, doi:10.1038/nature09455, 2010.

Vutukuru, S., Griffin, R. J., and Dabdub, D.: Simulation and analysis of secondary organic aerosol dynamics in the South Coast Air Basin of California, J. Geophys. Res.-Atmos., 111, D10s12, doi:10.1029/2005jd006139, 2006.

Wang, B., O’Brien, R. Kelly, S. T., Shilling, J. E., Moffet, R. C., Gilles, M. K., and Laskin, A.: Reactivity of liquid and semisolid secondary organic carbon with chloride and nitrate in atmospheric aerosols, J. Phys. Chem. A., 119, 4498-4508, doi:10.1021/jp510336q, 2015.

Wang, B. B., Lambe, A. T., Massoli, P., Onasch, T. B., Davidovits, P., Worsnop, D. R., and Knopf, D. A.: The deposition ice nucleation and immersion freezing potential of amorphous secondary organic aerosol: Pathways for ice and mixedphase cloud formation, J. Geophys. Res.-Atmos., 117, D16209, doi:10.1029/2012jd018063, 2012.

Watanabe, K., Yanuar, and Udagawa, H.: Drag reduction of Newtonian fluid in a circular pipe with a highly water-repellent wall, J. Fluid Mech., 381, 225-238, doi:10.1017/S0022112098003747, 1999.

Wilson, T. W., Murray, B. J., Wagner, R., Möhler, O., Saathoff, H., Schnaiter, M., Skrotzki, J., Price, H. C., Malkin, T. L., Dobbie, S., and Al-Jumur, S. M. R. K.: Glassy aerosols with a range of compositions nucleate ice heterogeneously at cirrus temperatures, Atmos. Chem. Phys., 12, 8611-8632, doi:10.5194/acp-128611-2012, 2012.

Zaveri, R. A., Easter, R. C., Shilling, J. E., and Seinfeld, J. H.: Modeling kinetic partitioning of secondary organic aerosol and size distribution dynamics: representing effects of volatility, phase state, and particle-phase reaction, Atmos. Chem. Phys., 14, 5153-5181, doi:10.5194/acp-14-5153-2014, 2014.

Zelenyuk, A., Imre, D., Beranek, J., Abramson, E., Wilson, J., and Shrivastava, M.: Synergy between secondary organic aerosols and long-range transport of polycyclic aromatic hydrocarbons, Environ. Sci. Technol., 46, 12459-12466, doi:10.1021/Es302743z, 2012. 
Zhang, Q., Jimenez, J. L., Canagaratna, M. R., Allan, J. D., Coe, H., Ulbrich, I., Alfarra, M. R., Takami, A., Middlebrook, A. M., Sun, Y. L., Dzepina, K., Dunlea, E., Docherty, K., DeCarlo, P. F., Salcedo, D., Onasch, T., Jayne, J. T., Miyoshi, T., Shimono, A., Hatakeyama, S., Takegawa, N., Kondo, Y., Schneider, J., Drewnick, F., Borrmann, S., Weimer, S., Demerjian, K., Williams, P., Bower, K., Bahreini, R., Cottrell, L., Griffin, R. J., Rautiainen, J., Sun, J. Y., Zhang, Y. M., and Worsnop, D. R.: Ubiquity and dominance of oxygenated species in organic aerosols in anthropogenically-influenced Northern Hemisphere midlatitudes, Geophys. Res. Lett., 34, L13801, doi:10.1029/2007g1029979, 2007.
Zhou, S. M., Shiraiwa, M., McWhinney, R. D., Pöschl, U., and Abbatt, J. P. D.: Kinetic limitations in gas-particle reactions arising from slow diffusion in secondary organic aerosol, Faraday Discuss., 165, 391-406, doi:10.1039/C3fd00030c, 2013.

Zhu, L. W., Neto, C., and Attard, P.: Reliable measurements of interfacial slip by colloid probe atomic force microscopy. III. shear-rate-dependent slip, Langmuir, 28, 34653473, doi:10.1021/La204566h, 2012. 